\title{
Direitos Humanos na aula de Química: um relato de experiência a partir da aplicação da Lei 10.639/2003
}

\section{Human Rights in Chemistry Class: a experience report from law enforcement 10.639/2003}

\author{
${ }^{1}$ Renata Barbosa Dionysio \\ ${ }^{1}$ Gilberto da Conceição Amorim \\ ${ }^{1}$ Roberto Dalmo Varallo Lima de Oliveira
}

\section{RESUMO}

A lei 10.639/03 torna obrigatório o ensino de história e cultura Africana e afro-brasileira. Desse modo o presente trabalho tem como proposta estabelecer uma conexão entre o Ensino de Química e a Lei 10.639/03, de forma a oportunizar discussões sobre as violações dos Direitos Humanos sofridas pelos afrodescendentes, sem deixar de lado os conteúdos químicos presentes no currículo escolar do Ensino Médio. Dessa forma, teve-se como objetivo relatar a experiência de uma aula de Química que buscou levar ao alunado de uma escola pública em Araguaína, Tocantins, uma discussão sobre Direitos Humanos e racismo, a partir de uma abordagem da Química das proteínas. Primeiramente aplicou-se uma lista de exercícios, em seguida ocorreu um debate sobre racismo, gerado a partir da utilização de dois vídeos. Posterior ao debate ocorreu à explicação sobre proteína. Para findar a metodologia uma segunda lista de exercícios foi aplicada. Trabalhar na perspectiva da lei 10.639/03 com viés em Direito Humanos ainda é algo recente, mas necessário. Através da análise das respostas percebemos inicialmente que grande parte alunos não possuíam muitas informações sobre proteínas, entretanto alguns sabiam que a proteína melanina que dá a coloração a pele. A partir do questionário inicial foi possível fazer a caracterização da turma, o que nos forneceu informações sobre quais as disciplinas que trabalharam com racismo anteriormente, e sobre a identidade étnica de cada estudante. Através dessa árdua e motivadora tarefa, percebemos que o Ensino de Química tem muito a contribuir no sentido de desconstrução de paradigmas em torno dos negros.

Palavras-chaves: Direitos Humanos; Racismo, Melanina.

\section{ABSTRACT}

The law 10.639/03 makes african and afro-brazilian history teaching obligatory in Brazil. Thus, the present study aims to establish a connection between the teaching of chemistry and the Law 10.639/03, in a manner that allow discussions about the violations of human rights and the racism suffered by afrodescendents, not forgetting the chemical content present in the high school curriculum. This way, our objective was to report the experience of a chemistry class that aimed to bring to the students from a public school in Araguaína, Tocantins, a discussion about human rights and racism, applying an approach on protein chemistry. At first, an exercise list was applied, followed by a debate on racism, created after the vídeos presentation. After this debate, there was an explanation about proteins. To finish the methodology, a second exercise list was applied. Working on the perspective of the Law 10.639/03 with an envisage in human rights is something still recent, but necessary. Through the analysis of the answers we observed that at first the students didn't have much information about proteins, however some knew that melanin confers the skin color. From the

1 UFT - Universidade Federal do Tocantins, Araguaína, TO. 
first questionnaire it was possible to characterize the class, what gave us informations about which disciplines worked previously with racism, and about the ethnical identity of each student. Through this hard and motivating task, we observed that chemistry teaching has much to contribute in the sense of deconstruction of paradigms around Black people.

keywords: human rights; racism; melanin.

\section{INTRODUÇÃO}

A Declaração Universal dos Direitos Humanos, afirma que todo cidadão possui o direito à igualdade, à vida, à liberdade, à moradia, ao trabalho decente, à educação, à saúde, entre outros. A garantia desses direitos possibilita a construção de uma sociedade mais justa e plural. Trabalhar em uma perspectiva de Direitos Humanos na sala de aula de Química é tão importante quanto trabalhar com o conteúdo propriamente dito. Assim, torna-se cada vez mais urgente a construção de práticas pedagógicas que possibilitem a formação de valores sociais, e que estimulem nos alunos o respeito às diferenças existentes em sala de aula e na sociedade em que estão inseridos (DALLARI, 1998).

A busca por uma educação em ciência com viés em Direitos Humanos enfrenta/enfrentará dificuldades para a sua implementação. Seja por causa de uma escola focada apenas nos conteúdos científicos ou ainda devido à falta de formação de professores de ciências nesse sentido.

Construir uma aula de ciências que vá ao encontro dos Direitos Humanos é uma batalha contra um modelo de escola que, por possuir grande dificuldade de diálogo com as diferenças, encontrou como solução o silêncio. Seria uma luta contra os discursos do "Somos responsáveis apenas pelo conteúdo de Ciências", do "não tenho tempo para isso", do "não fui formado para isso" e do "isso é responsabilidade dos professores de filosofia e sociologia”. Esses fatores fazem o ato de educar para a valorização das diferenças e para a luta contra as violações de direitos humanos ser um intenso e árduo "nadar contra a corrente”, sendo impossível e inviável pensar em mudanças significativas nas aulas de Ciências da Educação Básica, no que se refere aos Direitos Humanos, sem pensar a formação do Professor de Ciências (Oliveira, 2014. p. 16).

Educação em Química em uma perspectiva de Direitos Humanos é recente, desse modo gera dúvidas relacionadas à melhor maneira de se pôr em prática, além de gerar reflexão a partir da seguinte pergunta: Nós como professores de Química o que temos a ver com isso? Responderei a essa pergunta a partir da afirmação de Chassot (2004) em seu livro Para que (em) é útil o ensino? O mesmo enfatiza que "precisamos lutar por um ensino de Química que ofereça uma efetiva consciência de cidadania, de pensamento e capacidade”. A partir dessa concepção, evidencia que o professor de Química deve ter consciência que sua pratica educacional deva possibilitar a formação de um Estudante cidadão, que respeite e valorize a pluralidade humana.

Apesar de muitos anos terem se passado após a “abolição da escravidão”, a população negra - infelizmente - ainda sofre com o racismo. Segundo Passos (2002) a maioria dos autores dizem que o racismo está sustentado no seu caráter ideológico, ou seja, é a negação de direitos reais a um determinado grupo social. O racismo está presente nas atividades rotineiras e impede uma pessoa de gozar de direitos essenciais.

Na busca pelo enfrentamento dessa lógica racista e como fruto das organizações do Movimento Negro, que adquiriu mais força nos últimos anos do século XX - quando a política do país deu voz a movimentos sociais -, surgiu a Lei 10.639/2003 que reformula a LDB e torna obrigatório o ensino de História e Cultura Africana e Afro-Brasileira nas escolas públicas e privadas do Ensino Fundamental e Médio do país, preferencialmente nas disciplinas de Artes e História (LIMA, 2009)

A escola possui ferramentas para gerar mudanças no cenário vivido por diversos cidadãos afro-descendentes, Assim, trabalhar com essa lei contribui com o empoderamento dos afro-descendentes, uma vez que mui- 
tos se encontram entre os níveis de menor escolaridade, mais baixa renda e menores salários, quando conseguem acessar os empregos. Sem desconsiderar as questões de moradia, alimentação e acesso a cultura (GOMES e MARTINS, 2004).

\section{CAMINHO METODOLOGICO}

Como na estrutura curricular do Estado do Tocantins possui apenas um horário de 60 minutos por semana destinada a aulas de Química. Assim, nosso relato será sobre uma aula ministrada e que abordou o tema "racismo e proteínas”.

A aula teve início com a distribuição de um questionário com perguntas que objetivavam a descrição do perfil da turma, além de saber como os alunos estavam com o conteúdo proteínas. Esse questionário trazia questões que perguntavam aos alunos a idade, sexo e como se declaravam em relação à cor de sua pele. Além de perguntas sobre proteínas.

Após isso ocorreu à exibição de dois vídeos. O primeiro vídeo a ser trabalhado foi "Negro Drama”. O vídeo mostra a percepção do negro em relação a seu engajamento na sociedade, além de relatar suas dificuldades cotidianas e suas lutas ao longo da história do Brasil.

Ele é uma adaptação de um rap da banda Racionais Mc’s, é importante lembrar que o Rap faz parte da cultura negra brasileira. No vídeo a música é recitada por Seu Jorge, um Cantor negro, dando assim maior ênfase à letra da música.

O segundo vídeo trabalhado apresenta a opinião de uma jornalista frente a duas situações intrigantes. Na primeira situação ela defende um jovem branco que cometeu uma série de erros, na qual a frase marcante foi "Deixem o garoto ele está apenas crescendo". No caso do jovem negro a jornalista teve uma postura diferente... O garoto, preso, sem roupa, pelo pescoço a um poste, recebeu da jornalista o seu comentário "E aos defensores dos direitos humanos que se apiedaram do marginalzinho eu lanço uma campanha, Adote um bandido”.

Após a exibição dos referidos vídeos uma discussão foi realizada com os alunos. Nessa etapa os discentes através de suas falas demostraram suas opiniões sobre racismo e sobre a situação do negro no cenário nacional. Nesse momento os alunos foram questionados com as seguintes perguntas: "É justo julgar as pessoas de acordo com a cor de sua pele? O que dá tonalidade a cor da pele?” Após essas perguntas serem feitas foi explicado qual era o principal fator que dá tonalidade a cor da pele, no caso a melanina.

Nessa fase ainda trabalhou-se sobre alguns direitos primordiais para a construção de um cidadão de fato. A aula prosseguiu e chegou-se ao conteúdo curricular da Química.

O conteúdo trabalhado na aula foi proteínas. Trabalhando-se sobre aminoácidos, ligações peptídicas, estrutura primária, secundária, terciaria e quaternária das proteínas. Além de falar sobre as funções biológicas das proteínas e como a melanina e produzida pelo nosso corpo e quais são os processos químicos nessa produção, ressaltando os diferentes tipos de melaninas.

Para findar a aula, uma segunda lista de exercícios foi distribuída aos alunos. A lista de exercícios tinham questões relacionadas à importância de se trabalhar com discussões a respeito de temas como o racismo, direitos humanos e também perguntas relacionadas às proteínas.

Por fim para a análise dos resultados utilizamos a análise qualitativa proposta por (MORAES, 1999). Essa estratégia foi escolhida porque visa à descrição e interpretação de variados conteúdos, com o objetivo de investigação da teoria aliada à prática. Como foram aplicados dois questionários no decorrer da aula, a análise se procedeu da seguinte maneira. 
Para à análise do primeiro questionário o mesmo foi codificado como Q1. Cada aluno foi chamado por um código, para facilitar a identificação das suas falas. Desse modo os códigos foram de A1 a A15. As questões foram classificadas em três episódios sendo eles, "Episódio 1: Características da turma “, "Episódio 2: Direitos Humanos e Racismo " e "Episódio 3: Proteínas”. As respostas que estão contidas nos episódios foram classificadas e discutidas de acordo com algo em comum entre elas, para assim gerar discussões em torno das temáticas aqui pautadas.

O questionário 2 recebeu o código Q2. Como foi analisado as respostas dos alunos, cada aluno foi chamado por um código, no caso a turma contava com 15 alunos, então os códigos foram de B1 a B15. As perguntas que foram elaboradas estão relacionadas a duas linhas de conteúdos. A primeira e sobre Direitos Humanos e Racismo, a segunda linha sobre Proteínas. Em virtude disso as respostas foram analisadas nesses dois âmbitos, que aqui serão tratadas como "Episódio 1: Química, Direitos Humanos e Racismo" e "Episódio 2: Proteínas ”. Após a separação por episódios classificou as respostas de acordo com suas similaridades de ideias. Em seguida procuramos interpretar as respostas dos alunos de modo a gerar uma discussão em detrimento da proposta objetivada pelo referido trabalho.

\section{BREVE DESCRIÇÃO DO AMBIENTE ESCOLAR}

A escola na qual o trabalho foi realizado está localizada no perímetro urbano da Cidade de Araguaína-TO. Ela atende somente alunos que cursam as três séries do Ensino Médio regular, funcionando nos três turnos. A turma na qual a metodologia foi aplicada era da terceira série do Ensino Médio que contava com 15 alunos, com idade média de 17 anos.

\section{RESULTADOS E DISCUSSÕES}

\section{1 Análise das respostas dos estudantes ao Q1}

A análise de conteúdo do Q1 foi dividida previamente em três Episódios, denominados: "Episódio 1: Características da turma “, "Episódio 2: Direitos Humanos e Racismo ” e "Episódio 3: Proteínas”. Já as categorias presentes nos episódios foram nomeadas da seguinte maneira:

\section{Episódio 1: Características da turma:}

- Faixa etária da turma e sexo.

- Cor da pele

\section{Episódio 2: Direitos Humanos e Racismo:}

- Racismo como forma de violação dos Direitos Humanos

- A escola tem trabalhado no sentido de combate ao racismo?

\section{Episódio 3: Proteínas}

- Conceitos sobre Proteínas antes da aula

- Conceitos sobre Melanina antes da aula

\section{Episódio 1: Características da turma:}

A turma em que a estratégia didática foi empregada era formada por 15 alunos. Desses, doze eram do sexo feminino e apenas três do sexo masculino. A faixa etária da turma variava dos 16 aos 20 anos de idade. Com idade média de 17 anos. 
Já em relação à cor da pele, nove alunos se declararam “pardo”, um se declarou preto, outra se declarou indígena e três alunos se declararam amarelos. Um aluno não respondeu a pergunta referente à cor da pele. Um fato que chamou bastante atenção é que a sala apresenta mais de uma pessoa que se enquadrava na tonalidade de pele de cor preta e, portanto era negro.

Nesse instante é importante relatar que nem todos possuem uma identidade étnica, isso quer dizer que mesmo que, por mais que a pessoa seja negra, não é assim que ela se identifica. Desse modo é pertinente lembrar que a lei aqui em destaquei (Lei 10.639/03) assim como outras políticas de afirmações, surgem no intuito de valorização e construção da identidade étnica, por meio de práticas que quebrem os paradigmas e preconceitos construídos ao longo da história a respeito de um determinado grupo étnico.

\section{Episódio 2: Direitos Humanos e Racismo:}

Início esse episódio dizendo que inúmeros direitos dos cidadãos são violados quando a pessoa é vítima do racismo. Dessa maneira o segundo episódio preocupou-se em saber se algum dos alunos já sofreu racismo no ambiente escolar, ou se presenciou outro colega ser vitima de tal situação. Questionamos também se alguma disciplina tem trabalhado com essa temática.

Ao serem questionados se já tinham sido vítimas de racismo, todos os alunos responderam "NÃO”. Uma resposta na qual chamou a atenção foi do A10 "Não sofri, porque não sou preta". Essa frase apresenta uma ampla possibilidade de reflexões. Inicialmente acreditamos que não há uma maldade por parte do aluno, mas um racismo que se explicita a partir da sua fala.

Esse racismo se apresenta em pequenos gestos, às vezes de maneira tão sucinta que não é percebido. Talvez essa sutileza seja o propulsor de tantos “NÃO” por parte dos alunos. Com base nessa informação podemos dizer que alguns Direitos Humanos são violentados de maneira tão discreta (ou não) que não há uma percepção. O modelo de sociedade excludente brasileira, sempre colocou os negros à margem, essa longa história de inferiorizarão e desprezo dos negros já é algo cultural, e as violações de seus direitos já é tido como algo "normal” que muitas vezes não é percebida pelos violentados.

Quando questionados se presenciaram algum colega sofrer racismo apenas um aluno respondeu “sim”, mas não ressaltou se ajudou o colega ou não. Segundo as respostas dos alunos disciplinas como sociologia, português e artes tem trabalhado com o tema racismo. Ressaltando aqui que embora a lei 10.639/03 seja preferencialmente aplicada nas aulas de Artes e História, professores de outras disciplinas têm trabalhado com a referida lei.

Através da analise das questões evidenciou-se que muitos dos alunos sabem a importância da promoção da igualdade, mas poucos sabem que para a igualdade existir é preciso respeitar e aceitar às diferenças. Através da aula tentamos ressaltar essa necessidade e por isso fez se necessário a discussão sobre a igualdade pautada no respeito às diferenças.

\section{Episódio 3: Proteínas}

O último episódio do Q1 se preocupou em saber se os alunos já sabiam algo relacionado ao conteúdo de proteínas, conteúdo que deve ser dado na terceira série do Ensino Médio. Desse modo, as questões desse episódio eram sobre o que são proteínas e suas funções para os seres vivos. Além de questionar se os alunos sabiam qual a principal substância que dá tonalidade a pele.

Somente dois alunos deram o conceito sobre o que são proteínas e suas funções biológicas, as respostas estão transcritas a seguir: A1: proteínas são substâncias orgânicas que desempenham funções enzimáticas, hormonais, de defesa e outros. A2: É uma substância que fornece um melhor desenvolvimento corporal. Já em relação à conceituação do que é melanina, muitos alunos se confundiram com suas funções biológicas, somente 
dois alunos responderam o que a pergunta propunha. O aluno A3 respondeu que "Melanina é um composto orgânico que está na pele que a protege melhor" já o aluno A4 disse que "Melanina é a denominação genérica de uma classe de compostos poliméricos derivados da tirosina, cuja principal função é a pigmentação e proteção contra a radiação solar”.

\section{2 Análise das respostas dos estudantes ao Q2}

Assim como na analise do Q1, o Q2 foi dividido em episódios, sendo eles: Episódio 1: Direitos Humanos e Racismo e Episódio 2: Proteínas. As categorias presentes nos episódios estão dispostas a seguir:

\section{Episódio 1: Química, Direitos Humanos e Racismo:}

- Química trabalhando racismo

- Direitos Humanos na busca pela igualdade

\section{Episódio 2: Proteínas}

- Conceitos sobre Proteínas após a aula

- Conceitos sobre Melanina após a aula

\section{Episódio 1: Química, Direitos Humanos e Racismo:}

Começarei esse episódio com a fala dos alunos sobre a importância de se discutir racismo na aula de Química. B1 "É bom para que se acabe, ou pelo menos se esclareça sobre o racismo. Para que todos possam conviver bem e sem preconceito", B7 “Aprender a respeitar as pessoas como elas são”, B6 "A importância de se discutir sobre racismo serve para acabar com os preconceitos, quebrar tabus em uma sociedade hipócrita”, B12 "É de grande importância, pois apesar de ser um tema bastante discutido, é sempre bom expor e trocar informações com colegas e com pessoas capacitadas, para conseguirmos viver num mundo mais justo". A fala dos alunos nos remete a uma questão interessante, a promoção da igualdade pautada no respeito às diferenças. Torna-se importante dizer que sete alunos da referida turma notou a necessidade de se discutir essa temática para eliminar ou pelo menos amenizar o racismo e, portanto, garantir a cidadania.

Os alunos restantes da turma dissertaram que a importância de se trabalhar com essa temática, é para possibilitar o entendimento da origem da cor da pele, assim como se conhecer mais sobre melanina. A seguir está a fala de alguns alunos, com essa concepção da aula. B2 "Para entendermos a relação entre a cor da pele e a melanina”, B5 "Para entendermos que todos possuímos uma proteína, que é a melanina, na qual determina a cor da pele" e B12 "É importante para explicar o surgimento da cor da pele". Embora mais da metade da turma tenha se ligado mais ao conteúdo químico, uma quantidade significativa notou a importância de se trabalhar com esse tema na aula de Química. Com base nessa dualidade de pensamentos podemos dizer que: embora a educação que vá em direção dos Direitos Humanos é construída à passos curtos, não pode ser deixada de lado, pois é através de uma educação cidadã que as mazelas do preconceito podem ser amenizados.

A penúltima questão proposta para os alunos instigava os mesmos a fazerem uma reflexão sobre a aula. Veja as respostas de alguns alunos. B1: "A aula de hoje mostrou que há muitas pessoas racistas, que de forma direta ou indiretamente praticam isso. Além da aula ter mostrado que a melanina possui funções além da coloração da pele", B4: "Que não devemos excluir as pessoas não importa a cor da pele”, B7 "Mostrou que nossa sociedade deveria ter respeito", B6 "transmitiu questões de cidadania e sobre o preconceito "racismo" na atualidade". Ao fazer a análise de cada fala percebemos que caminhamos um pouco para a conscientização dos alunos em detrimento da igualdade com base no respeito às diferenças.

Por fim pedimos aos alunos que escrevessem uma frase que caracterizasse a aula dada. As frases dos alunos foram motivadoras no sentido de mesmo que ainda não mudou muita coisa na cabeça deles, mas algo mudou e isso já é algo bom no que se refere à proposta de construção de uma sociedade que valorize e respeite a 
pluralidade. Desse modo encerro esse episódio com a frase dos alunos. B15 “Não devemos olhar para a cor da pele, mas para o caráter das pessoas", B10 "Nunca julgue um livro pela capa, assim como nunca julgar um ser humano pela cor da pele” B11 “Cor não define caráter” e B1”Independente de nossa cor somos todos iguais”.

\section{Episódio 2: Proteínas}

Um dos objetivos da aula era levar informações sobre o que são proteínas, em particular a melanina. Desse modo abordamos as características principais dessa classe de substância. Para facilitar a aprendiza dos alunos utilizou-se slides, esses continha imagens representando as estruturas das proteínas, além de possuírem informações sobre as funções biológicas e outras características. Para sabermos se os alunos conseguiram entender algo sobre esse conteúdo elaboramos três questões que perguntavam sobre o que são proteínas e suas funções biológicas, além de questionar sobre as funções da melanina e o que é. Desse modo algumas respostas serão transcritas a seguir.

Quando perguntados sobre o conceito de proteínas e suas funções biológicas os alunos responderam que B1: "Proteínas são macromoléculas biológicas constituídas por uma ou mais cadeia de aminoácido", B15: Proteína é um composto orgânico, ela é importante para o desenvolvimento dos músculos e pele. B8: "É um composto orgânico, que possui diferentes funções no corpo humano. Entre essas funções está a de transporte de oxigênio", B9: "É um conjunto de aminoácido. Com função de possibilitar fortalecimento ao corpo". Com base nas respostas dos alunos é importante ressaltar que grandes maiorias conseguiram entender o conteúdo exposto, mas nem todos os alunos conseguiram elaborar uma resposta coerente referente à pergunta.

Em relação à conceituação da proteína melanina e suas funções biológicas nos mamíferos. Veja as respostas de alguns alunos: B11 "É proteína substância responsável pela cor da pele, olhos e cabelo", B14 "é o que dá a coloração a pele" B7 "é uma proteína que confere cor a pele e nos protege do sol”. Torna-se cabível dizer nesse momento que os alunos conseguiram entender as funções da melanina e o que a mesma é. Ressaltando aqui que ocorreu uma discussão até chegarmos ao conteúdo proteínas. A discussão teve início com a questão dos Direitos Humanos, chegou as violações desses referidos direitos por causa do racismo e enfim chegamos ao conteúdo da Química que era objetivado.

\section{CONSIDERAÇÕES FINAIS}

Nossa proposta de trabalho foi estabelecer uma conexão entre Ensino de Química e a Lei 10.639, de forma que fosse possível ocorrer discussões sobre as violações dos Direitos Humanos sofridas pelos afrodescendentes sem deixar de lado os conteúdos químicos presentes no currículo escolar do Ensino Médio. Essa tarefa, de início, aparentou ser complexa, uma vez que, além de envolver o tema racismo - tema bastante controverso -, teríamos que envolver discussões sobre proteínas e cor de pele.

Com intuito de iniciar as discussões em torno da temática racismo, dois vídeos foram exibidos, de forma que buscou-se instigar uma reflexão sobre a situação dos negros em nossa sociedade. Além disso, como nosso trabalho pretendia abordar o conteúdo de proteínas, procuramos saber por meio de um questionário inicial quais os conhecimentos que os alunos possuíam sobre esse assunto.

Através da análise das respostas percebemos inicialmente que grande parte alunos não possuíam muitas informações sobre proteínas, entretanto alguns alunos sabiam que é a melanina que dá a coloração a pele. Também a partir do questionário inicial foi possível fazer a caracterização da turma, o que nos forneceu informações sobre quais as disciplinas que trabalharam com racismo anteriormente, e sobre a identidade étnica de cada estudante. Algo que chamou bastante atenção nas respostas é que alguns alunos embora sejam negros não se identificaram assim. 
Após a aula os alunos responderam a um questionário final contendo perguntas que buscavam investigar o que os alunos compreenderam sobre os tópicos abordados durante a aula. Ao analisar as respostas evidenciou-se que os discentes conseguiram responder as questões sobre proteínas (melanina) e compreenderam que a química pode ser uma aliada na formação de pessoas que respeitem as diferenças étnico-raciais.

Embora a Lei 10.639 seja preferencialmente trabalhada pelas disciplinas de Artes e História, ela deve ser estendida as outras disciplinas. O trabalho aqui descrito buscou mostrar a importância de se aplicar essa lei no Ensino de Química. Acreditamos que uma sala de aula que busque práticas que promovam discussões sobre a valorização e o respeito às diferenças possibilita o florescer de uma sociedade menos excludente.

Trabalhar na perspectiva da lei 10.639/03 com viés em Direito Humanos ainda é algo recente, mas necessário. Através dessa árdua e motivadora tarefa, percebemos que o Ensino de Química tem muito a contribuir no sentido de desconstrução de paradigmas em torno dos negros.

\section{REFERÊNCIAS BIBLIOGRÁFICAS}

CHASSOT, A. I. Para que(m) é útil o ensino? Canoas: Editora da ULBRA, 2004.

DALLARI, D. A. Direitos humanos e cidadania. São Paulo: Editora Moderna, 1998.

GOMES, N. L.; MARTINS, A. A. Afirmando direitos: acesso e permanência de jovens negros na universidade. Belo Horizonte: Editora Autêntica, 2004.

LIMA, A. C. G. (orgs) et al. Diálogos interculturais, currículo e educação: experiências e pesquisas antirracistas com crianças na educação básica. Rio de Janeiro: Editora Quartet, 2009.

MORAES, Roque. Análise de conteúdo. Porto Alegre: Revista Educação, v. 22, n. 37, 1999.

OLIVEIRA, R. D. V. L. O. - Notas de Aula da Disciplina Cultura brasileira e questões étnicos- raciais. Tocantins: Universidade Federal do Tocantins, 13/11/2014.

PASSOS, J. C. Discutindo as relações raciais na estrutura escolar e construindo uma pedagogia multirracial e popular. In. NOGUEIRA, João Carlos (Org.). Multiculturalismo e a pedagogia multirracial e popular. Florianópolis: Editora Atilènde, 2002. 